\title{
Environmental Valuation in Indonesia Implication for forest policy, legal liability and state losses estimates
}

\author{
Jacob Phelps, Bernadeta Hariyanti, Anna Christina Sinaga and Ahmad Dermawan
}

\begin{abstract}
Introduction
Tropical ecosystems provide a wide and complex range of goods and services to individuals and communities (Box 1). These diverse environmental values include: direct-use values related to natural resources that can be managed and extracted (e.g. timber, minerals and non-timber forest products) and indirectuse values associated with biodiversity and ecosystem services (e.g. hydrological, pollination and climate regulation services, recreation and tourism). Nature also holds intrinsic values and non-use cultural, religious and historical values.
\end{abstract}

There are growing efforts to quantify and assign financial values to these diverse goods and services. These values can be used to inform trade-off analysis, decision making, and calculation of taxes and payment schemes. They can also be used to calculate damages when the environment is harmed.

When ecosystems are destroyed or degraded, the impacts on natural resources, biodiversity and ecosystem services can represent huge losses to the state, society and individuals. In Indonesia, such losses are tremendous (see Myers et al. 2000; Hansen et al. 2013). For example, Human Rights Watch (HRW 2009) estimated that in 2006 Indonesia lost almost US\$2 billion from untaxed illegal logging. In 2013, the Indonesian State Auditor reported 26 mining and plantation companies for illegal forest encroachment resulting in state losses equivalent to approximately US\$7.7 million (BPK 2013). The use and non-use impacts of these damages are potentially orders of magnitude greater (e.g. MAPPI 2012; see van Beukering et al. 2009).

Assigning a value to these environmental damages represents a vital area of research and policy development (White and Heckenberg 2011). The valuation of environmental damages can aid efforts to prosecute activities such as illegal logging, wildlife trafficking, agricultural encroachment into forests and associated corruption. Where perpetrators can be found financially liable for ensuing damages, valuation has the potential to strengthen prosecution, deter potential perpetrators, ensure restitution to injured parties and recover resources for ecosystem restoration and rehabilitation. This was notably illustrated through the landmark 1989 case following the Exxon Valdez oil spill along the United States' Pacific coast. A growing number of countries are making efforts to quantify and value these impacts to strengthen environmental governance (e.g. Schopp and Pendergrass 2003; EC 2004).

\section{Box 1. Diverse types of environmental values}

Environmental valuation includes a diverse and complex set of values that can be conceptualized in a number of ways. For example, Willis and Garrod (1996) identify:

Direct-use values: Resources for extraction, water services, recreation and tourism

Indirect-use values: Climate regulation, physical protection Non-use values: Option value (i.e. willingness to pay), existence value (i.e. value of knowing the resource exits) Intrinsic values: Values not tied to human use

These goods, services and values are intertwined to form complex socio-ecological systems, such that provision of one benefit is often tied to the function of many others. This highlights the importance of a broad approach to environmental valuation that considers many different values across landscapes, and how these collectively provide goods and services valued by society. Broad accounting also considers diverse non-economic and non-material benefits, as well as the ways in which environmental benefits are differently experienced and valued across stakeholder groups.
Indonesia is among the countries seeking to financially account for these environmental damages, and in 2011 articulated a valuation approach for civil cases following environmental damages. ${ }^{1}$ There is growing experience with its application, including the 2014 ruling against PT Kallista Alam for illegally burning peatland forest in Aceh Province, which held the company financially responsible for damaged ecosystems.

Environmental valuation efforts are also emerging in several other contexts. For example, several ministries are pursuing independent 'green accounting' efforts to better

1 Ministry of the Environment Decree Number 13/2011 on Compensation of Pollution and Environmental Damages 
recognize natural capital stocks. ${ }^{2}$ Forest carbon stocks are also increasingly quantified to support Indonesia's commitments to climate change mitigation through Reducing Emissions from Deforestation and Degradation (REDD+). ${ }^{3}$ In 2014 The Ministry of National Development Planning (BAPPENAS - Badan Perencanaan Pembangunan Nasional), supported by the World Bank's WAVES Program, ${ }^{4}$ began an initiative to coordinate environmental valuation efforts across Indonesian agencies to inform planning and sustainable development. These initiatives represent a significant change of approach, as Indonesian law has traditionally only recognized the financial value of natural resources with extractive potential (e.g. timber and minerals).

However, there remains a lack of clarity regarding how valuations are operationalized and used in Indonesia, including uncertainty over the objectives, methods, definitions and legal precedents. Tackling these issues requires broad enquiry into the objectives of valuation, as well as technical support, research, capacity building, legal reform and cross-institutional collaboration.

To this end, CIFOR hosted an exploratory focus group discussion (FGD) on Indonesian approaches to environmental valuation. It focused on the use of valuation in cases of liability for egregious and large-scale environmental damages, to help inform civil cases, state loss calculations and criminal cases, particularly of corruption. ${ }^{5}$ The event drew participants from 11 institutions ${ }^{6}$ for a far-reaching discussion on current approaches to valuation. This InfoBrief identifies five overlapping themes (Box 2) that can help academe, government and civil society build a common agenda for research, collaboration and policy development related to environmental valuation.

2 For example, Ministry of Finance scoping study on environmental valuation; Ministry of the Environment Decree Number 15/2012 on Economic Valuation Guidelines on Forest Ecosystem

3 Presidential Decree Number 62/2013 on the Implementation Body for Reducing Emissions from Deforestation and Degradation on Forests and Peatlands states that carbon stocks will be measured according to methods identified by the Indonesian REDD+ Agency.

4 The Wealth Accounting and Valuation of Ecosystem Services (WAVES) program is a collaboration between the World Bank, UN agencies and partner governments to implement natural capital accounting in tropical developing countries, linked to the international System of Environmental Economic Accounting (SEEA). See: https://www.wavespartnership.org/en/ system-environmental-economic-accounting-seea.

5 The focus, as such, is explicitly on instances involving large-scale environmental damage and corruption, rather than on small infractions or the 'low-level' perpetrators of environmental damage.

6 Hosted at CIFOR in Bogor, Indonesia, 13-14 May 2014. Institutions represented: Attorney General Office (Kejaksaan Agung Republik Indonesia), Indonesian National Police (Kepolisian Republik Indonesia), Corruption Eradication Commission (Komisi Pemberantasan Korupsi), State Auditor (Badan Pemeriksa Keuangan, BPK), Financial and Development Supervisory Board (Badan Pemeriksaan Keuangan dan Pembangunan), Ministry of Forestry (Kementerian Kehutanan), Ministry of Agriculture (Kementerian Pertanian), Ministry of Finance (Kementerian Keuangan), Bogor Agricultural Institute (Institut Pertanian Bogor), Indonesian Corruption Watch (ICW) and Forest Watch Indonesia (FWI). The Ministry of Environment was unable to attend the FGD, but their preliminary inputs were fed into this report. Inputs have also been added following meetings with BAPPENAS, UNORCID and the World Bank WAVES Program.

\section{Box 2. Emerging themes for research, collaboration and policy}

1. Define valuation objectives and approaches

2. Identify appropriate valuation methods

- Define what environmental benefits are valued

- Collect best practices

- Ensure data demands are realistic and reliable

3. Clarify role of valuation in legal proceedings

4. Consider the politics of valuation

5. Anticipate broader implications of valuation

\section{Theme 1. Define objectives and approaches to valuation}

Environmental valuation in Indonesia involves a number of government agencies, beyond those traditionally associated with forest management. However, emerging approaches are often not harmonized, and also differ from international guidelines and approaches proposed by some civil society groups (e.g. HRW 2009). Arguments are also made against quantification and valuation, and their unintended consequences (see Theme 5). As such, there is need to engage diverse stakeholders to articulate objectives, consider limitations and define the most appropriate strategies.

Cross-agency cooperation on valuation is particularly complex in the context of environmental litigation and liability. For example, investigations are generally led by the National Police, who determine the nature of the case, and decide which other agencies should be involved. Where there are indications of state losses associated with corruption, the police can directly enlist the help of the Supreme Audit Board (BPK) and the Development and Financial Supervisory Board (BPKP) to calculate these losses, to inform their criminal prosecution. The Anti-Corruption Commission (KPK) also has a role, and can independently investigate and prosecute corruption in the forest sector, including over state losses. However, such calculations of state loss are also shaped by the State's definition of "assets", which is determined by the law.

Where other types of environmental damages are evident (e.g., pollution that impacts public health, destruction of biodiversity), the Ministry of Environment is often called upon to demonstrate and quantify these damages. Police and public prosecutors prepare and submit civil or criminal indictments that can include valuation assessments to the court. Finally, if penalties are levied court, there is a need to ensure that associated fines or compensation are actually collected (Butler 2014).

However, current valuation approaches vary across ministries. For example, the State Auditors (BPK, BPKP) have traditionally focused on timber values, following existing legal definitions of state assets. Conversely, BAPPENAS plans to promote a much broader approach based on the international System of Environmental-Economic Accounting (SEEA 2014).? The Ministry of Environment has also

7 Developed by international experts through the United Nations Statistical Commission, the SEEA contains standards for concepts, definitions and rules for producing statistics on the relationships between the environment and economy. 
taken a broad approach, considering use and non-use values in the calculation of punitive damages from environmental damages, ${ }^{8}$ and for valuation of natural resources for policy making and land-use planning. ${ }^{9}$ The Directorate General of State Assets of the Ministry of Finance, which is responsible for conducting valuations of all state assets, has also adopted a broad approach, seeking to establish a comprehensive natural resource balance sheet. The Ministry of Forests, while traditionally focused on valuation for taxes, licenses and tariffs associated with timber and non-timber forest products, recently extended its scope to consider 32 different sources of forest-based revenue, including licensing fees associated with aesthetic services, carbon sequestration and hydrological services. ${ }^{10}$

Environmental valuation thus requires engagement across agencies (see Laurans et al. 2013), and there is a need to inventory and harmonize emerging approaches. While different methods have emerged, in part, based on individual institutions' responsibilities and authority, stakeholders also understand valuation in very different ways. Each of the stakeholders have different views on the services that should be prioritized, the methods that are appropriate, as well as the needs, opportunities, challenges and consequences associated with valuation. As such, there is a need for broad stakeholder engagement to define objectives and approaches (see Theme 2). This will require fora for improved exchange, capacity building and cross-institutional knowledge sharing

\section{Theme 2. Identify appropriate valuation methods}

Discussions with different government actors reveal significant interest in standardized valuation methods, to ensure coherence across agencies and contexts, and to provide legal certainty. There exist a wide range of methods that can be used for environmental valuation, which have been the focus of both academic and political debates (see Jones 1997; Carson 1998). However, a lack of standardization across contexts and agencies in Indonesia led to some uncertainty and, consequently, a reluctance to use valuation into the courtroom.

Critically, identifying appropriate methods requires wide stakeholder engagement, testing different approaches and encouraging the development of innovative approaches, all as part of a structured and iterative learning process. In addition, the process must assess technical aspects as well as legal, political and procedural dimensions. The process of identifying valuation approaches will require efforts to define what benefits are valued, collect best practices from other contexts and ensure that demands are realistic.

8 Ministry of the Environment Decree Number 13/2011 on Compensation of Pollution and Environmental Damages

9 Ministry of the Environment Decree Number 15/2012 on Economic Valuation Guidelines on Forest Ecosystem

10 Government Regulation Number 12/2014 on Tariff of Non-tax Revenue Prevailing to the Ministry of Forestry
Define what environmental benefits are valued

Ecosystems provide benefits with a wide range of values. However, even in the context of broad valuation approaches, there are practical and normative dimensions to selecting which services are valued. For example, there are broad critiques that valuation often fails to account for various non-material and nonmonetary environmental values (i.e. religious, relational, cultural, ecological; Gómez-Baggethun and Ruiz-Pèrez 2011; Chan et al. 2012), yet there is ongoing debate about whether non-use values should be prioritized in calculations intended for courtroom use (Kontoleon et al. 2002). There are also suggestions that valuation could focus on services with greatest market potential, such as water, ecotourism and carbon stocks (van Beukering et al. 2009). There are practical considerations, as not all ecosystem services are comparable. Biodiversity, for example, is a likely policy priority, but is also notoriously challenging to quantify and value (Nijkamp et al. 2008). Defining what services are valued influences methods, demands, effort and cost. Moreover, defining what services are valued also depends on objectives, which are shaped by different stakeholder priorities and politics (see Theme 4).

\section{Collect best practices}

There is considerable scope to learn from other countries about accounting standards, as well as operationalizing and utilizing valuation. The international SEEA standard is likely to provide a helpful starting point for discussions in Indonesia. The United States has particularly well-documented experience in applying valuation to legal cases (e.g. Jones 1997). Similarly, emerging experiences from the European Community (e.g. Loureiro 2014) and other tropical developing countries can help to inform efforts in Indonesia. These standards and examples can offer valuable insight into the types of valuation approaches and methods that may be viable in the tropics (e.g. Carson 1998).

\section{Ensure data demands are realistic and reliable}

Data availability and quality present leading challenges to valuation (e.g. Troy and Wilson 2006), especially in the context of tropical developing countries. There is a need to ensure methods are practical and affordable. Experience to date already highlights the challenges of operationalizing valuation in Indonesia. ${ }^{11}$

Yet there are cases where valuation is being operationalized successfully, including in relatively cost-effective ways (e.g. Harrison and Lesley 1996). There is also scope to draw on standard default values ${ }^{12}$ as well as benefits transfer, where estimates from one valuation study are used to inform other cases. These approaches are particularly helpful when there are resource limitations, a lack of expertise or time constrains that stand in the way of full case-by-case assessments. However, these

11 For example, although timber values are legally recognized, government reference pricing for timber has remained far below market prices. The 2012 Ministry of Environment guidelines on resource valuation have not yet been implemented; Ministry of the Environment Decree Number 15/2012 on Economic Valuation Guidelines on Forest Ecosystem. 12 The 2011 Ministry of Environment Decree on Compensation of Pollution and Environmental Damages includes a number of default values for a number of ecosystem services. 
efforts also rely on establishing credible datasets and realistic and reliable methods through which to quantify values.

\section{Theme 3. Clarify role of valuation in legal proceedings}

There is mounting interest in the use of valuation to inform legal proceedings, and Indonesia has growing experience in the use of valuation and environmental liability in civil cases. However, a lack of clarity regarding the precise role of valuation in Indonesian courtrooms has generated some uncertainty over whether environmental valuation can be applied in different contexts, particularly in the context of criminal charges for corruption and ensuing state losses. Legal review is needed to increase clarity over the scope, objectives and legal statutes for using valuation in Indonesian courtrooms.

Notably, the use of valuation is shaped by legal context. Existing definitional barriers and uncertainty limit efforts to ensure the formal recognition of broader environmental values. For example, a number of laws and regulations equate environmental benefits only with extractive potential. Definitions of 'state loss' (kerugian negara), 'state financial loss' (kerugian keuangan negara) and 'state asset' (kekayaan negara) face similar limitations..$^{13}$ If environmental goods, services and values are not recognized as state assets, damage assessments may not be able to formally account for them as state losses. Additionally, these definitions are associated with different pieces of legislation, which potentially limits their use in contexts that involve broader environmental values. Indonesia also lacks a consolidated map that clearly designates different forest and land uses, which adds further legal uncertainty.

There is also a need to assess the compatibility of laws, civil and criminal processes, and non-courtroom adjudication measures. For example, existing valuation guidelines for calculating environmental damages in civil cases could potentially also inform state loss calculations and criminal charges of corruption (e.g. where corruption impacts the state's environmental assets). There is need to explore the links among different types of penalties to ensure a coherent criminal justice strategy that is both fair and effective (e.g. administrative infractions, criminal acts, guidelines on forest revenues, fines, civil damages, state loss calculations, anti-corruption and anti-money laundering laws).

Successful application of valuation in legal contexts further requires insight into how environmental valuation is understood, substantiated and interpreted within the courtroom setting. Especially in the absence of clear guidelines, there may be scope for public prosecutors to draw on expert witnesses and research to support valuation claims. There is similarly a need to explore the standing of certain types of valuation methods in the courtroom, such as stated preference methods to calculate nonuse values, and the use of benefits transfer and default values (see Arrow et al. 1993). Prosecutor and judicial perceptions and interpretations of valuation need to be better understood, as they help to determine standards of practice.

13 These refer respectively to Law Number 31/1999, updated by Law Number 20/2001 on the Eradication of Corruption, Law Number 17/2003 on State Finances, Law Number 1/2004 on State Treasury.
Given the costs of implementing environmental valuation, and its limitations in the courtroom, there is a clear need to determine the contexts under which it is an appropriate tool (Swanson and Kontoleon, n.d.). For example, valuation is likely most appropriate when dealing with large, conspicuous damages, rather than when considering comparatively minor infractions, and there is a clear need to distinguish among these different types of cases (see White and Heckenberg 2011).

\section{Theme 4. Consider the politics of valuation}

While often treated as an accounting exercise, valuation is an intensely political process. Decisions about why resources are valued, what resources are valued and at what prices, are influenced by asymmetrical assertions of stakeholder interests, engagement, power and voice. Debates are particularly acute where valuation is likely to increase penalties, inform resource and land allocation, and/or challenge powerful interests (see Smith et al. 2003).

The political nature of valuation is exemplified by the ways in which the Indonesian state has historically determined reference pricing for timber. The government revised the reference price of timber in 2012, long after the 2007 price was declared as no longer applicable. While there are a number of possible explanations, this reference price has significant impacts on taxation, and it is plausible that the price has been kept low due to vested interests.

Similarly, in the United States, lobbyists voicing industry opposition to the use of valuation within environmental cases have proven to be a powerful political force (e.g. Randall 1993) This reinforces the need for coordination across agencies, clear understanding regarding the objectives of valuation, and private sector engagement. It also highlights the need to recognize that valuation is part of larger governance processes (e.g. mediating the relations among industry and government regulations) rather than an isolated activity (cf. Butler 2014).

Inter-ministerial conflicts also politicize valuation debates, as agencies have different interests and hold overlapping responsibilities, complicating implementation and potentially resulting in disagreement over the management of valuable resources.

\section{Theme 5. Anticipate broader implications of valuation}

Environmental valuation has far-reaching implications for forest and resource management. For example, a timber reference price that also accounts for ecological values could affect not only environmental damage assessments, but also taxation rates for the timber industry. Valuation could also shift cost-benefit analyses in ways that can affect decision making about issues such as spatial planning.

Critically, valuation can also yield negative consequences. In strict financial terms, cost-benefit analyses could favor resource extraction over conservation or sustainable management (see van Beukering et al. 2009). Equally, there is the risk that promoting valuation could result in ecosystem substitution 
(e.g. United States' Tradable Development Rights), where in some contexts environmental damages are compensated by creating 'comparable' ecosystems or services in other places. This may not represent a desirable or practical strategy in the context of many tropical ecosystems (see Walker et al. 2009). As such, there is a need for upfront, critical thinking about the implications of valuation.

\section{Conclusions}

Valuation is often treated as a neutral, technical exercise that relies on identifying the most accurate methods and tools. In fact, there is clear need for a broader process to establish common objectives, approaches and methods, based on robust science, different stakeholder interests, cost and logistics. In this way, there is a need to simultaneously address technical, legal, scientific and political dimensions of valuation, while integrating it into broader efforts to strengthen natural resource and forest management.

Such progress will require a thorough review of existing practices across Indonesian agencies, as well as consideration of international guidelines and environmental valuation practices in other countries. It will also require increased interagency engagement, and a broader, iterative learning process to ensure that valuation meets stated objectives (cf. Almer and Goeschl 2010). Given the broad, cross-sector implications of environmental valuation, accounting efforts merit deeper exploration and debate. This InfoBrief highlights key issues for these discussions in Indonesia and other tropical countries seeking to use valuation, to promote more sustainable development and effective criminal justice strategies.

\section{Acknowledgement}

This Infobrief is funded by DFID KnowFor and U4 - ACRC (AntiCorruption Resource (enter) The authors would like to thank to individual who participated in the FGD (Listed in footnote number 6) and who provided inputs for the improvement of the InfoBrief (Ministry of Environment, BAPPENAS, UNORCID, WAVES Program World Bank, and Central Statistics Agency)

\section{References}

Almer A and Goeschl T. 2010. Environmental crime and punishment: Empirical evidence from the German penal code. Land Economics 86:707-26.

Arrow K, Solow R, Portney PR, Leamer EE, Radner R and Schuman H. 1993. Report of the NOAA Panel on Contingent Valuation. Federal Register 58:4601-14.

[BPK] Badan Pemeriksa Keuangan. 2013. Temuan korupsi Sekitar Tambang. Warta BPK. Accessed 17 June 2014. http://www. bpk.go.id/magazine/majalah-bpk

Butler R. 2014. In precedent-setting case, palm oil company fined $\$ 30 \mathrm{M}$ for destroying orangutan forest. Mongabay, 9 January 2014. Accessed 15 January 2014. http://news. mongabay.com/2014/0109-aceh-tripa-court-decision. html\#4uuaJQzIYkD5QfH7.99

Carson RT. 1998. Valuation of tropical rainforests: philosophical and practical issues in the use of contingent valuation. Ecological Economics 24:15-29.
Chan KMA, Guerry A, Balvanera P, Klain S, Satterfield T, Basurto X, Bostrom A, Chuenpagdee R, Gould R, Halpern BS, Hannahs N, Levine J, Norton B, Ruckelshaus M, Russel R, Tam J, Woodside U 2012. Where are cultural and social in ecosystem services? A framework for constructive engagement. BioScience 62:744-56.

[EC] European Community. 2004. Environmental Liability, Directive 2004/35/EC. Accessed 17 June 2014. http://ec.europa. eu/environment/legal/liability/

Gómez-Baggethun E and Ruiz-Pérez M. 2011. Economic valuation and the commodification of ecosystem services. Progress in Physical Geography 35:613-28.

Hansen M.C., Potapov P.V., Moore R., et al. 2013. High-resolution global maps of 21 st-century forest cover change. Science 342:850-3.

Harrison GW and Lesley JC. 1996. Must contingent valuation surveys cost so much? Journal of Environmental Economics and Management 31:79-95.

[HRW] Human Rights Watch. 2009. Wild money, The human rights consequences of illegal logging and corruption in Indonesia's forestry sector. New York USA: Human Rights Watch. Accessed 17 June 2014. http://www.hrw.org/reports/2009/12/01/wildmoney-0

Jones CA. 1997. Compensation for natural resource damages from oil spills: A comparison of USA law and international conventions, and pollution. International Journal of Environment and Pollution 11:86-107.

Kontoleon A, Macrory R and Swanson T. 2002. Individual preference-based values and environmental decision making: Should valuation have its day in court? Research in Law and Economics 20:179-216.

Laurans Y, Rankovic A, Bille R, Pirard R and Mermet L. 2013. Use of ecosystem services economic valuation for decision making: Questioning a literature blindspot. Journal of Environmental Management 119:208-19.

Loureiro ML. 2014. Claiming environmental damages in the Prestige oil spill court case (Spain). Association of Environmental and Resource Economists 34:20-4.

[MAPPI] Masyarakat Pemantau Peradilan Indonesia. 2012. Case analysis of corruption case on permit in forestry sector, evaluation and legalization of annual working plan IUPHHK HT 12 industrial plant companies, 2005-2006, Riau Province. MAPPI, Fakultas Hukum, Universitas Indonesia, Jakarta, Indonesia.

Myers N, Mittermeier RA, Mittermeier GC, da Fonseca GAB and Kent J. 2000. Biodiversity hotspots for conservation priorities. Nature 403:853-5.

Nijkamp P, Vindigni G and Nunes PALD. 2008. Economic valuation of biodiversity: A comparative study. Ecological Economics 67:217-31.

Randall A. 1993. Passive-use values and contingent valuation: valid for damage assessment. Choices 8:12-15.

Schopp D and Pendergrass J. 2003. Natural resource valuation and damage assessment in Nigeria: A comparative analysis. Washington, DC: Environmental Law Institute. Accessed 10 February 2014. http://www.eli.org/research-report/ natural-resource-valuation-and-damage-assessment-nigeriacomparative-analysis.

[SEEA] System of Environmental-Economic Accounting. 2014. New York, NY: United Nations Statistical Commission. Accessed 22 August 2014. http://unstats.un.org/unsd/envaccounting/ seearev/ 
Smith J, Obidzinski K, Subarudi, Suramenggala I. 2003. Illegal logging, collusive corruption and fragmented governments in Kalimantan, Indonesia. International Forestry Review 5:293-302.

Swanson T and Kontoleon A. n.d. What is the role of environmental valuation in the courtroom? The US experience and the proposed EU Directive. Accessed 12 December 2013. https://www.elaw.org/system/files/Environmental.Valuation. Courtroom.pdf

Troy A and Wilson MA. 2006. Mapping ecosystem services: practical challenges and opportunities in linking GIS and value transfer. Environmental Economics 60:435-49.

[UNEP] United Nations Environment Programme. 2011. Towards a green economy. Geneva: United Nations Environment Programme. Accessed 17 June 2014. www.unep.org/ greeneconomy van Beukering P, Grogan K, Hansfort SL and Seager D. 2009. An economic valuation of Aceh's forests: The road towards sustainable development. Report number R-09/14 for Fauna \& Flora International. Accessed 15 June 2014. http://dare.ubvu.vu.nl/ bitstream/handle/1871/20934/R09-14.pdf? sequence $=2$

Walker S, Brower AL, Stephens RT and Lee WG. 2009. Why bartering biodiversity fails. Conservation Letters 2:149-57.

[WAVES] Wealth Accounting and the Valuation of Ecosystem Services. Washington, DC: The World Bank. Accessed 22 August 2014. https://www.wavespartnership.org/en

White $R$ and Heckenberg D. 2011. Environmental horizon scanning and criminological theory and practice. European Journal of Criminal Policy and Research 17:87-100.

Willis K and Garrod G. 1996. Towards a methodology for costing biodiversity conservation in the UK. London: Department of the Environment.

\begin{tabular}{|c|c|c|}
\hline CGIAR & $\begin{array}{l}\text { RESEARCH } \\
\text { PROGRAM ON } \\
\text { Forests, Trees and } \\
\text { Agroforestry }\end{array}$ & $\begin{array}{l}\text { This research was carried out by CIFOR as part of the CGIAR Research Program on Forests, Trees and } \\
\text { Agroforestry (CRP-FTA). This collaborative program aims to enhance the management and use of } \\
\text { forests, agroforestry and tree genetic resources across the landscape from forests to farms. CIFOR } \\
\text { leads CRP-FTA in partnership with Bioversity International, CATIE, CIRAD, the International Center for } \\
\text { Tropical Agriculture and the World Agroforestry Centre. }\end{array}$ \\
\hline
\end{tabular}

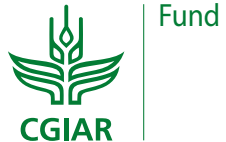

